gramas atuais. Estamos perante uma obra útil no presente, mas também no futuro, independentemente das alterações programáticas que vierem a ocorrer.

Como os autores referem, "mais importante do que discutir se o trabalho prático deve ou não deve ser realizado no ensino das ciências é discutir como utilizá-lo de modo eficaz". De facto, parece consensual que o ensino prático e experimental desempenha um papel fundamental na Educação em Ciência. No entanto, apesar da prática laboratorial ser consignada como obrigatória nos programas atualmente em vigor, a realidade mostra que per-

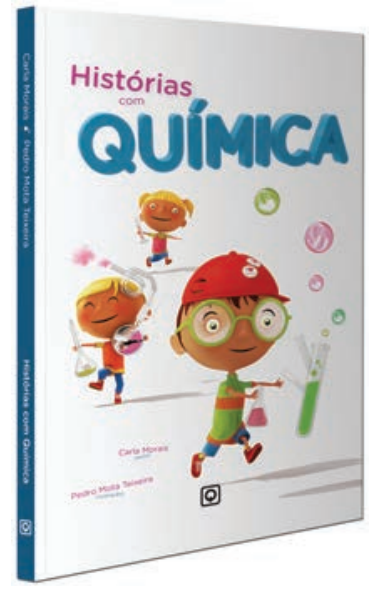

Este livro surge do reconhecimento de que o ensino das ciências nos primeiros anos de escolaridade pode contribuir de forma decisiva para a promoção da literacia científica, potenciando o desenvolvimento de competências necessárias ao exercício de uma cidadania interveniente e informada e à posterior inserção numa vida profissional qualificada e ligada a áreas científicas.

Contando histórias - nas quais os valores e o conteúdo informativo podem ser apresentados, principalmente, por meio de aspetos lúdicos, distribuindo informações científicas ao longo de

* Faculdade de Ciências da Universidade do Porto E-mail: jcpaiva@fc.up.pt siste ainda uma percentagem elevada de professores de Ciências que dedica um tempo muitíssimo reduzido ao ensino experimental. As razões que eventualmente originam este comportamento são, talvez, medos e insegurança, decorrentes de uma provável formação inicial deficiente. Além disso, muitos docentes que valorizam e não descuram o trabalho laboratorial/ experimental não o fazem de maneira profícua. É dada primazia a demonstrações e verificações experimentais, bem como a metodologias reveladoras de fraca atualização didática no que diz respeito ao modo como devem ser realizadas com eficácia as atividades práticas de laboratório.
A preocupação constante que ressalta da leitura deste livro é a de ser útil e de poder contribuir eficazmente para um ensino melhor. Contém todo um saber adquirido e consolidado na experiência, na utilização no terreno, no cuidado com a formação, na atualização didática proveniente da investigação.

Elaborado com grande rigor, profundidade e cuidado, constitui, de facto, não só um excelente meio de atualização, como um grande apoio à resolução de dificuldades e um forte estímulo à realização adequada e eficaz da prática experimental-laboratorial no Ensino da Física e da Química.

\title{
HISTÓRIAS COM QUÍMICA
}

JoÃo PaIVA*

\author{
Autores: Carla Morais e Pedro Mota Teixeira \\ Editora: QuidNovi \\ N. ${ }^{\circ}$ páginas: 96 \\ ISBN: 978-989-554-910-8
}

uma narrativa ficcional, onde há lugar para coloridas naves espaciais e viagens no interior das estrelas, ou ainda para conversas com um mocho sobre densidade e elementos químicos poderá contribuir-se para despertar a curiosidade e preparar o cérebro dos mais jovens para o processamento de conhecimentos mais intrincados.

Ao longo das histórias, e sempre que oportuno, sublinha-se o carater eminentemente experimental da ciência química. É também na aproximação entre a química e a pasta de dentes rica em flúor que se desenha uma via de sensibilização para a importância da higiene oral ou ainda para a necessidade de ter uma prática desportiva regular, bem como uma alimentação saudável e equilibrada. O jogo tradicional do anelzinho surge como pretexto para se conhecer a alquimia e o desejo de transmutação dos metais, bem como o enxofre, o azoto, o fósforo e o potássio na aproximação às dinâmicas da vida rural nas vinhas do Douro.

Neste livro, onde as informações precisas e complexas do meio científico são condensadas em linguagem acessível e histórias que se deseja sejam atraentes, bem como em propostas práticas e experiências científicas simples, o convite é desafiante: experienciar o território das histórias e do lúdico para nele aprender, com fascínio, o grande fascínio da química.

\section{O QUIIMICAI}


